\title{
Batch and fixed-bed assessment of sulphate removal by the weak base ion exchange resin Amberlyst A21
}

\author{
Damaris Guimarães*, Versiane A. Leão \\ Bio\&Hydrometallurgy Laboratory, Department of Metallurgical and Materials Engineering, Universidade Federal de Ouro Preto, Campus Morro do Cruzeiro, \\ s.n., Bauxita, Ouro Preto, MG, 35400-000, Brazil
}

\section{H I G H L I G H T S}

- Amberlyst A21 (weak base resin) was applied for the first time in sulphate removal.

- It is a comprehensive study of the main aspects of sulphate adsorption, never done before.

- Sulphate adsorption process by Amberlyst A21 is fast and feasible in acid medium.

- Efficient sulphate elution was obtained using simple and accessible conditions.

\section{A R T I C L E I N F O}

\section{Article history:}

Received 20 February 2014

Received in revised form 4 July 2014

Accepted 26 July 2014

Available online 13 August 2014

\section{Keywords:}

Sulphate removal

Sorption

Ion exchange

Amberlyst A21

Weak base resins

\begin{abstract}
A B S T R A C T
This paper investigated sulphate removal from aqueous solutions by Amberlyst A21, a polystyrene weak base ion exchange resin. Both the $\mathrm{pH}$ and initial sulphate concentration were observed to strongly affect sorption yields, which were largest in acidic environments. Working under optimum operational conditions, sulphate sorption by Amberlyst A21 was relatively fast and reached equilibrium after $45 \mathrm{~min}$ of contact between the solid and liquid phases. Sorption kinetics could be described by either the pseudo-first order $\left(k_{1}=3.05 \times 10^{-5} \mathrm{~s}^{-1}\right)$ or pseudo-second order model $\left(k_{2}=1.67 \times 10^{-4} \mathrm{~s}^{-1}\right)$, and both the Freundlich and Langmuir models successfully fitted the equilibrium data. Sulphate uptake by Amberlyst A21 was a physisorption process $\left(\Delta H=-25.06 \mathrm{~kJ} \mathrm{~mol}^{-1}\right)$ that occurred with entropy reduction $\left(\Delta S=-0.042 \mathrm{~kJ} \mathrm{~mol}^{-1} \mathrm{~K}^{-1}\right)$. Elution experiments showed that sulphate is easily desorbed $(\sim 100 \%)$ from the resin by sodium hydroxide solutions at $\mathrm{pH} 10$ or $\mathrm{pH} 12$. Fixed-bed experiments assessed the effects of the initial sulphate concentration, bed height and flow rate on the breakthrough curves and the efficiency of the Amberlyst A21 in the treatment of a real effluent. In all studied conditions, the maximum sulphate loading resin varied between 8 and $40 \mathrm{mg}\left(\mathrm{SO}_{4}{ }^{2-}\right) \mathrm{mL}(\text { resin })^{-1}$.
\end{abstract}

(c) 2014 Elsevier B.V. All rights reserved.

\section{Introduction}

When oxidizing conditions are present, sulphate is the predominant sulphur species in liquid effluents associated with the processing sulphur-laden raw materials $[1,2]$. High sulphate levels in water and wastewaters are related to the occurrence of piping and equipment corrosion, and, when such effluents are discharged into the environment, they may increase the acidity of both soils and bodies of water [1,3].

Among wastewaters containing high sulphate concentrations, acid mine drainage (AMD) is one of the most important. AMD is generated when sulphide minerals are oxidized in the presence of

\footnotetext{
* Corresponding author. Tel.: +55 313559 1102; fax: +55 3135591561

E-mail address: guimaraes.damaris@yahoo.com.br (D. Guimarães).
}

water and oxygen, either with or without the aid of bacteria. This acidic solution acts as a leaching agent for different minerals, producing a drainage rich in dissolved metals, which can render natural waters unsafe for use, even after mining activities have ceased [4]. High sulphate concentrations in drinking water cause taste alteration and, when the sulphate content exceeds $600 \mathrm{mg} \mathrm{L}^{-1}$, diarrhoea [2]. Because of these adverse effects to human health and the environment, mining countries usually set limits for sulphate concentrations in waters and wastewaters ranging from $250 \mathrm{mg} \mathrm{L}^{-1}$ to $500 \mathrm{mg} \mathrm{L}^{-1}[2,5]$.

Sulphate emissions can be controlled by combinations of different techniques such as lime neutralization and gypsum precipitation, reverse osmosis, electrodialysis and adsorption [1]. Although the application of adsorption is often limited to the polishing step of wastewater treatment, it is a promising method due to its ability to reduce sulphate ion concentrations to very low levels 
[6]. Moreover, its relative cost can be reduced by selecting a suitable resin and working under conditions that maximize adsorption and also facilitate regeneration. Sulphate removal by shrimp peelings [7], modified cellulose contained in both sugarcane bagasse [8] and rice straw [9], coconut pith [10], limestone [11] and modified zeolites [12] have been proposed. Feng et al. [13] devised a process for AMD treatment comprised of metal precipitation and sulphate sorption on ion exchange resins. Nevertheless, a fundamental assessment of sulphate sorption mechanisms is yet to be carried out. Within such a context, the present study sought to investigate the utilization of Amberlyst A21, a weak base resin, for sulphate sorption because this material confers the advantage of easy elution via $\mathrm{pH}$ shift.

\section{Experimental}

\subsection{Amberlyst A21 resin}

Amberlyst A21 is a weak base (tertiary amine) macroporous polystyrene resin with an exchange capacity of $1.25 \mathrm{eq} \mathrm{L}^{-1}$ [14]. Prior to the experiments, the resin was sieved using Tyler sieves, and a particle size range between $0.71 \mathrm{~mm}$ and $0.84 \mathrm{~mm}$ was selected for all experiments. Samples were kept under water for at least $40 \mathrm{~h}$ before use in the experiments.

\subsection{Batch sorption and elution}

The influence of both $\mathrm{pH}(2,4,6,8$ and 10) and initial anion concentration on sulphate uptake was studied by placing $1 \mathrm{~mL}$ of hydrated resin in contact with $100 \mathrm{~mL}$ of sodium sulphate solutions with $\mathrm{SO}_{4}{ }^{2-}$ concentrations ranging from 100 to $1200 \mathrm{mg} \mathrm{L}^{-1}$. The experiments were performed over $5 \mathrm{~h}$, during which the system was stirred at $180 \mathrm{~min}^{-1}$ while temperature $\left(34^{\circ} \mathrm{C}, 50^{\circ} \mathrm{C}\right.$ or $70^{\circ} \mathrm{C}$ ) and solution $\mathrm{pH}$ were constant. At the end of the experiments, the samples were filtered, and the sulphate concentration in the aqueous phase was determined by ICP-OES (Inductively Coupled Plasma-Optical Emission Spectroscopy). Sulphate loadings in the resins were determined by mass balance.

The kinetic of the sorption was also studied. In this step, $5 \mathrm{~mL}$ of hydrated resin were mixed with $1 \mathrm{~L}$ of solution containing $160 \mathrm{mg}\left(\mathrm{SO}_{4}{ }^{2-}\right) \mathrm{L}^{-1}$ at $28 \pm 1^{\circ} \mathrm{C}$ and $\mathrm{pH} 4$, which were kept constant throughout the experiment. The system was sampled every $5 \mathrm{~min}$ in the first hour, every $10 \mathrm{~min}$ in the second hour, and at 140 , $160,180,210,240$ and $360 \mathrm{~min}$. Sorption data were then fitted to pseudo-first order, pseudo-second order and intraparticle diffusion models [15].

The pseudo-first order model assumes that the sorption process is reversible and reaches equilibrium. This model is represented by Eq. (1), where $k_{1}$ is the overall rate constant for the pseudo-first order model, $t$ is time and $U_{t}$ the fractional attainment of equilibrium. $U_{t}$ is obtained by Eq. (2). Such a model can only be applied to data from to the lower part of the resin loading curve; i.e., the model does not apply to equilibrium data [15].

$\ln \left(1-U_{t}\right)=-k_{1} t$

$U_{t}=\frac{q}{q_{\mathrm{eq}}}=\frac{C_{\mathrm{o}}-C}{C_{\mathrm{o}}-C_{\mathrm{eq}}}$

The pseudo-second order model (Eq. (3)) was proposed by Ho and McKay [18] to describe sorption processes in which the ratedetermining step is the sorption reaction. In this equation, $k_{2}$ is the rate constant of the pseudo-second order model, and $q_{t}$ and $q_{\infty}$ are the sulphate loading achieved at time $t$ and at equilibrium, respectively.

$q_{t}=\frac{t k_{2}\left(q_{\infty}\right)^{2}}{1+t k_{2} q_{\infty}}$

The intraparticle diffusion model proposed by Weber and Morris [19] is valid if adsorbate diffusion in the liquid film is the only controlling step of the process. This model is described by Eq. (4), in which $k_{\text {ip }}$ is the rate constant of intraparticle diffusion, and $C$ is a constant related to the thickness of the boundary layer.

$q=k_{\mathrm{ip}}(t)^{1 / 2}+C$

Sorption equilibrium was investigated using adsorption isotherms produced at different temperatures, which enabled a thermodynamic analysis of sulphate sorption. The isotherms were produced by mixing $1 \mathrm{~mL}$ of hydrated resin with $100 \mathrm{~mL}$ of sodium sulphate solutions whose initial sulphate concentrations varied between $30 \mathrm{mg} \mathrm{L}^{-1}$ and $1800 \mathrm{mg} \mathrm{L}^{-1}$. Each system was stirred at $180 \mathrm{~min}^{-1}, \mathrm{pH} 4$ and a temperature of $34^{\circ} \mathrm{C}, 50^{\circ} \mathrm{C}$ or $70^{\circ} \mathrm{C}$ until equilibrium was reached. The aqueous phase was subsequently separated from the solid phase, and the residual aqueous sulphate concentration was determined by ICP-OES. Resin loading was determined by mass balance. Equilibrium data were then fitted to the Freundlich and Langmuir models [14] prior to thermodynamic analysis.

The Langmuir model (Eq. (5)) was originally developed to represent monolayer adsorption on ideal surfaces. It assumes that the heat of adsorption is independent of surface coverage and is similar to that observed in chemical reactions. Further assumptions are: (i) there is a limited and measurable area for adsorption; (ii) the monolayer is one molecule thick; and (iii) adsorption is reversible, and equilibrium conditions are attained [6]. Conversely, the Freundlich isotherm (Eq. (6)) is an empirical equation that describes non-ideal adsorption processes. It assumes heterogeneous surfaces and multilayer adsorption [20], resulting in an exponential distribution of the heats of adsorption [6].

$q_{\mathrm{eq}}=\frac{q_{\mathrm{max}} b C_{\mathrm{eq}}}{1+b C_{\mathrm{eq}}}$

$q_{\mathrm{eq}}=K_{\mathrm{f}}\left(C_{\mathrm{eq}}\right)^{1 / n}$

In Eqs. (5) and (6), $q_{\mathrm{eq}}$ is the resin loading at equilibrium, $C_{\mathrm{eq}}$ is the equilibrium concentration of the adsorbate in solution, $q_{\max }$ is the maximum loading, $b$ is a constant related to the affinity between the resin and the adsorbate, $K_{\mathrm{f}}$ is the capacity factor, and $n$ is the intensity parameter [6].

A thermodynamic analysis used data produced for the initial sulphate concentration of $300 \mathrm{mg} \mathrm{L}^{-1}$ was carried out to assess the influence of temperature on the sorption process. Equilibrium constant $\left(K_{\mathrm{eq}}\right)$ values corresponding to the sorption process developed at different temperatures were determined utilizing Eq. (7):

$K_{\mathrm{eq}}=\frac{q_{\mathrm{eq}}}{C_{\mathrm{eq}}}$

The equilibrium constant, as written in Eq. (7), is also called the distribution coefficient $\left(K_{\mathrm{D}}\right)$ [24-26]. After obtaining $K_{\text {eq }}$, the enthalpy $(\Delta H)$ and entropy $(\Delta S)$ of sulphate sorption were determined from the van't Hoff equation (Eq. (8)), and the Gibbs free energy was calculated by Eq. (9).

$\ln K_{\mathrm{eq}}=-\frac{\Delta H}{R T}+\frac{\Delta S}{R}$

$\Delta G=-R T \ln K_{\mathrm{eq}}$

In Eqs. (8) and (9), $R$ is the universal gas constant $\left(8.314 \mathrm{~J} \mathrm{~K}^{-1} \mathrm{~mol}^{-1}\right)$ and $T$ is the temperature. 
Table 1

Composition of the industrial effluent used experimentally.

\begin{tabular}{lr}
\hline Element/ion & Concentration $\left(\mathrm{mg} \mathrm{mL}^{-1}\right)$ \\
\hline $\mathrm{SO}_{4}$ & 98.41 \\
$\mathrm{~F}$ & 1.30 \\
$\mathrm{Cl}$ & 10.11 \\
$\mathrm{Al}$ & 0.02 \\
$\mathrm{As}$ total & 0.24 \\
$\mathrm{Cd}$ & $<0.05$ \\
$\mathrm{Ca}$ & 27.52 \\
$\mathrm{~Pb}$ & $<0.05$ \\
$\mathrm{Cu}$ & $<0.05$ \\
$\mathrm{Fe}$ & 0.02 \\
$\mathrm{Mg}$ & 3.12 \\
$\mathrm{Mn}$ & 0.08 \\
$\mathrm{Ni}$ & $<0.05$ \\
$\mathrm{~K}$ & 0.96 \\
$\mathrm{Na}$ & 0.92 \\
$\mathrm{Zn}$ & $<0.05$ \\
\hline
\end{tabular}

Sulphate elution from Amberlyst A21 was assessed by mixing $100 \mathrm{~mL}$ of sodium hydroxide solutions (at $\mathrm{pH} 10$ and $\mathrm{pH} 12$ ) with $1 \mathrm{~mL}$ of pre-loaded resin $\left(10.4 \mathrm{mg}\left(\mathrm{SO}_{4}{ }^{2-}\right) \mathrm{mL}(\text { resin })^{-1}\right)$. The system was kept under agitation for $24 \mathrm{~h}$ at $30^{\circ} \mathrm{C}$, and the final sulphate concentration in the aqueous phase was determined by ICP-OES prior to calculating resin elution efficiencies

\subsection{Fixed-bed experiments}

Sulphate adsorption in fixed-bed columns were performed in order to investigate the effects of concentration, bed height and flow rate on bed loading. Different volumes of resin $(0.71-0.84 \mathrm{~mm}$ particle sizes) were transferred to a glass column ( $13 \mathrm{~mm}$ diameter $\times 142 \mathrm{~mm}$ height) to produce different bed lengths, $Z(6 \mathrm{~cm}$, $9 \mathrm{~cm}$ and $12 \mathrm{~cm}$ ). After loading, distilled water was passed through the column (60 min) to remove fine particles that could have been loaded in the column. The column was fed upwards by peristaltic pumps so that any preferential pathway for the solution would be avoided. The flow rate $(Q)$ was varied between 10 and $20 \mathrm{~mL} \mathrm{~min}^{-1}$. Samples were collected regularly from the column effluent. The sulphate concentrations in these samples were analysed by ICP-OES. The inlet sulphate concentration $\left(C_{0}\right)$ ranged from $55 \mathrm{mg} \mathrm{L}^{-1}$ to $160 \mathrm{mg} \mathrm{L}^{-1}$, and the anion loading on the resin was determined by mass balance. The experiments were carried out at a $\mathrm{pH}$ of 4.0 and a temperature of $28 \pm 1{ }^{\circ} \mathrm{C}$.

To assess the efficiency of Amberlyst A21 in the treatment of a real effluent (from the mining industry), adsorption experiments were performed in a fixed-bed column. The composition of the acidic effluent ( $\mathrm{pH} 3.2$ ) is presented in Table 1 and the experiments were carried out at $25 \pm 1{ }^{\circ} \mathrm{C}$, using a bed height of $9 \mathrm{~cm}$, which was fed at a flow rate of $10 \mathrm{~mL} \mathrm{~min}^{-1}$. Immediately after loading the bed, it was eluted for $3 \mathrm{~h}$ with a $\mathrm{pH} 12$ sodium hydroxide solution at a flow rate of $10 \mathrm{~mL} \mathrm{~min}^{-1}$. The samples were collected in intervals of $10 \mathrm{~min}$ and the chloride and fluoride content were determined by ion chromatography (Metrohm).

\section{Results and discussion}

\subsection{Batch experiments}

As can be seen in Fig. 1, sulphate loadings in Amberlyst A21 were significantly reduced as the solution acidity decreased. This outcome was explained by the presence of tertiary amine groups, which must be positively charge in order to bind sulphate (Eq. (10)). Therefore, the concentration of protonated amine groups increased with increasing acidity, resulting in greater sulphate loading (Eq. (11)). Fig. 1 also indicates that increasing the initial anion
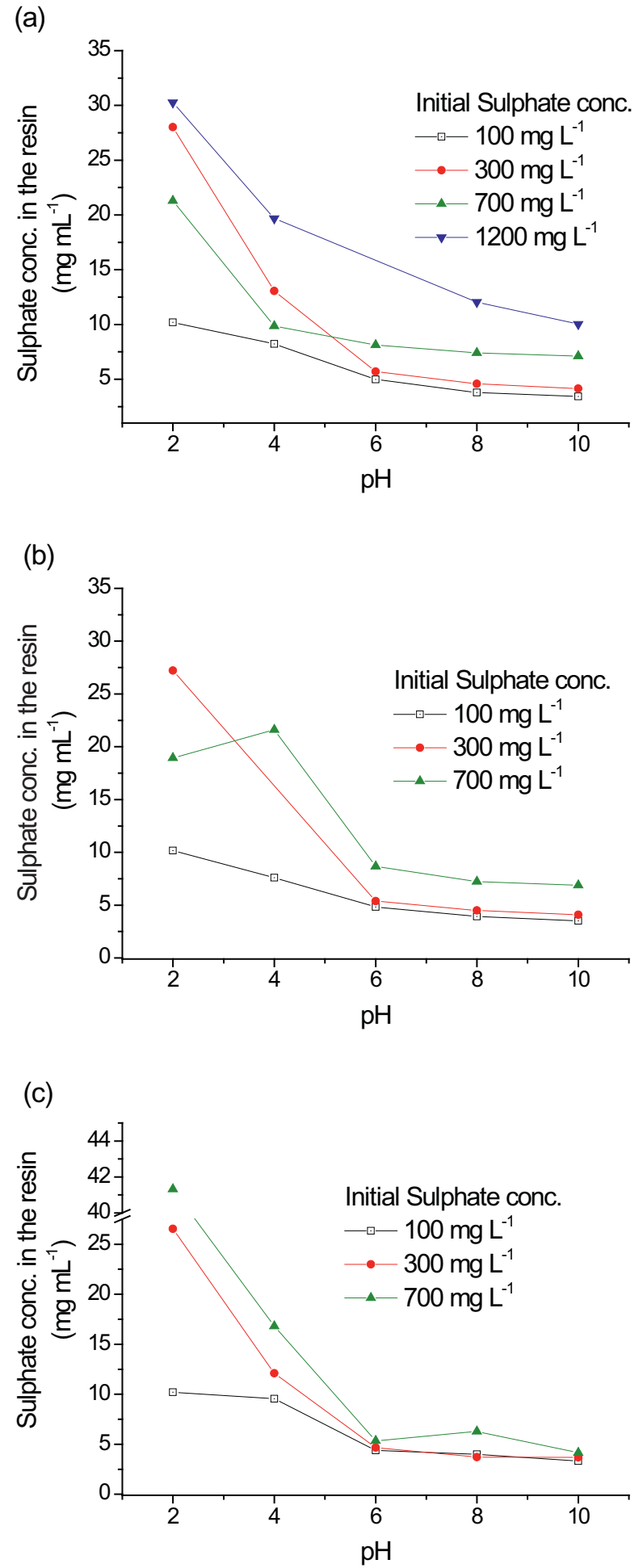

Fig. 1. Effect of $\mathrm{pH}$ on sulphate sorption by Amberlyst $\mathrm{A} 21$ resin at $34^{\circ} \mathrm{C}$ (a), $50^{\circ} \mathrm{C}$ (b) and $70^{\circ} \mathrm{C}(\mathrm{c})$. Experimental conditions: $1 \mathrm{~mL}$ of hydrated resin, $100 \mathrm{~mL}$ of solution and stirring rate of $180 \mathrm{~min}^{-1}$.

concentration resulted in larger sulphate loadings on Amberlyst A21. Conversely, sulphate loadings were slightly reduced at higher temperatures; this will be further discussed during the analysis of the effect of temperature on sorption equilibrium.

$\mathrm{R}-\mathrm{NH}_{3(\text { resin) }}+\mathrm{H}_{2} \mathrm{O} \leftrightarrows \mathrm{RNH}_{4}{ }^{+}{ }_{(\mathrm{resin})}+\mathrm{OH}^{-}{ }_{(\mathrm{aq})}$

$2 \mathrm{RNH}_{4}{ }^{+}{ }_{(\mathrm{resin})}+\mathrm{SO}_{4}{ }^{2-}{ }_{(\mathrm{aq})} \leftrightarrows\left(\mathrm{RNH}_{4}{ }^{+}\right)_{2}\left(\mathrm{SO}_{4}{ }^{2-}\right)_{(\mathrm{resin})}$ 


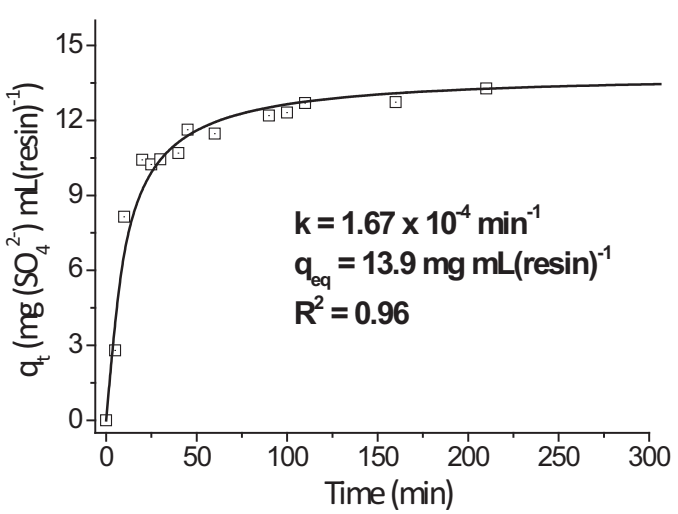

Fig. 2. Loading sulphate $\left(q_{t}\right)$ in function of time and fit of pseudo-second order model from adsorption essays by Amberlyst A21. Experimental conditions: $5 \mathrm{~mL}$ of hydrated resin, $1 \mathrm{~L}$ of sodium sulphate solution $\left(150 \mathrm{mg}\left(\mathrm{SO}_{4}{ }^{2-}\right) \mathrm{L}^{-1}\right)$, at $28 \pm 1{ }^{\circ} \mathrm{C}, \mathrm{pH}$ 4 , stirring rate of $200 \mathrm{~min}^{-1}$.

The $\mathrm{pH} 4$ was selected for further sulphate sorption studies because this $\mathrm{pH}$ is encountered in many AMD sites. Working at this $\mathrm{pH}$, Fig. 2 depicts the profile of the sulphate concentration in the resin as a function of time in a batch study. The sorption process, which was comprised of two different stages, resin protonation (Eq. (10)) and sulphate sorption (Eq. (11)), was relatively fast, attaining an equilibrium concentration of $11.6 \mathrm{mg} \mathrm{mL}(\text { resin })^{-1}$ in nearly $45 \mathrm{~min}$.

The kinetic data were fitted to pseudo-first order, pseudosecond order and intraparticle diffusion models. Among these models, only the pseudo-second order model showed a good fit to the experimental data and described all the data generated in the kinetic experiments. Thus, it can be inferred that this model describes the adsorption of sulphate by Amberlyst A21 resin. As shown in Fig. 2, the pseudo-second order rate constant was $1.67 \times 10^{-4} \mathrm{~s}^{-1}$ and the theoretical equilibrium sulphate loading $\left(q_{\infty}\right)$ was $13.9 \mathrm{mg} \mathrm{mL}(\text { resin })^{-1}$, which is consistent with the experimental value $\left.(11.6 \mathrm{mg} \mathrm{mL} \text { (resin })^{-1}\right)$. In studies of sulphate adsorption by another type of adsorbent, Oliveira [12] investigated the adsorption of sulphate in zeolites functionalized by barium salts. In this case, the process was described by the pseudo firstorder model with an overall rate constant of $0.4 \mathrm{~s}^{-1}$.

Subsequently, sorption equilibrium was investigated utilizing isotherms produced at different temperatures and fitted to both Langmuir (Eq. (5)) and Freundlich (Eq. (6)) models. Fig. 3 presents the fittings of the experimental data to the Langmuir

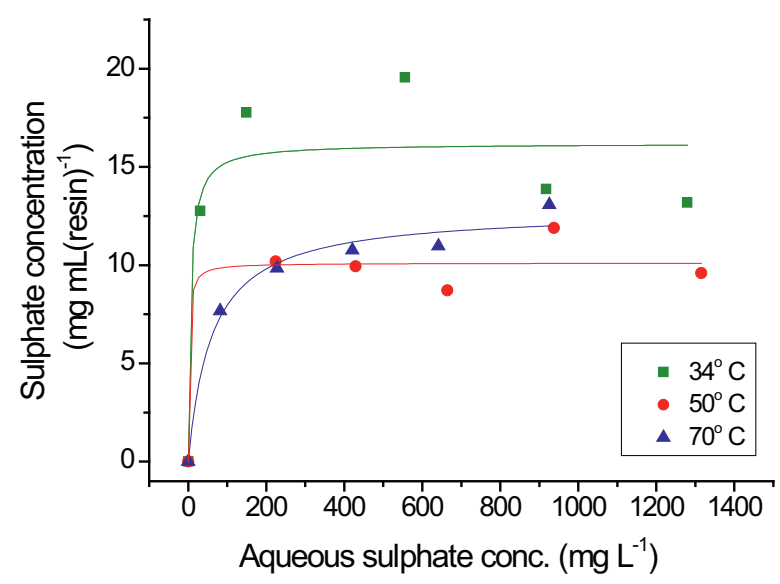

Fig. 3. Adsorption isotherms fitted to Langmuir model, constructed with data obtained from essays carried out in different conditions of temperature, $\mathrm{pH} 4$ and stirring rate of $180 \mathrm{~min}^{-1}$, with the Amberlyst A21 resin.
Table 2

Adsorption isotherms parameters of Langmuir model obtained at different temperatures, $\mathrm{pH} 4$ and stirring rate of $180 \mathrm{~min}^{-1}$, with Amberlyst A21 resin.

\begin{tabular}{lll}
\hline Temperature & Langmuir & \\
\cline { 2 - 3 } & Parameters & $R^{2}$ \\
\hline $34^{\circ} \mathrm{C}$ & $q_{\max }=16.18$ & 0.83 \\
& $b=0.16$ & \\
$50^{\circ} \mathrm{C}$ & $q_{\max }=12.78$ & 0.98 \\
& $b=0.15$ & \\
$70^{\circ} \mathrm{C}$ & $q_{\max }=10.11$ & 0.92 \\
& $b=0.06$ & \\
\hline
\end{tabular}

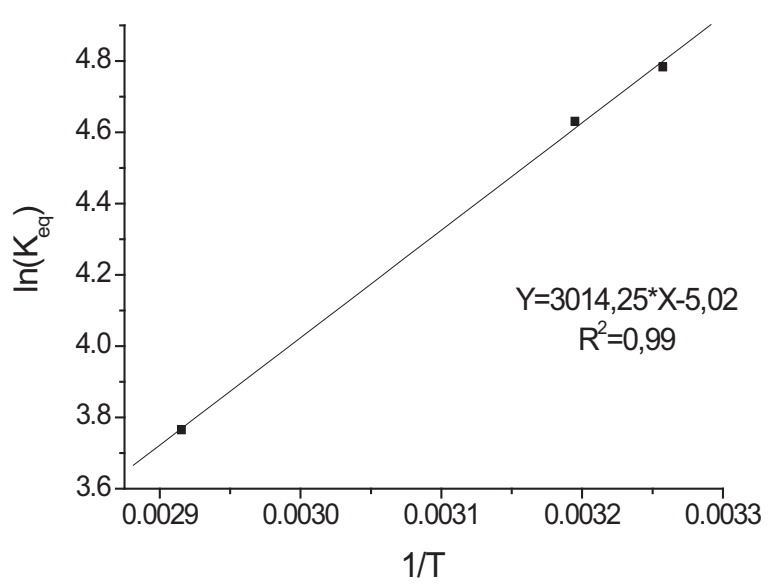

Fig. 4. van't Hoff plot for sulphate sorption on Amberlyst A21.

equation at different temperatures $\left(34^{\circ} \mathrm{C}, 50^{\circ} \mathrm{C}\right.$ and $\left.70^{\circ} \mathrm{C}\right)$; the Langmuir isotherm can be utilized to describe sulphate adsorption by Amberlyst A21, with $q_{\max }$ values close to $15 \mathrm{mg} \mathrm{mL}{\text { (resin })^{-1}}^{-}$ (Table 2). The observed $b$ constant values, also listed in Table 2, generally decreased with increasing temperature. As this constant is related to the affinity between sulphate and resin, it can be inferred that the affinity decreases as temperature increases [6]. Sorption data were also fitted to the Freundlich model, however, a good fitting was not observed in this case. Based on the analysis of the $R^{2}$ values, it can be stated that sulphate adsorption in Amberlyst A21 is described by the Langmuir model. This way, the surface of the loaded resin is composed of a monolayer of sulphate anions. Similar results were also observed by Haghsheno et al. [21] for the ion exchange resin Lewait K6362, by Namasivayam and Sangeetha [10] using $\mathrm{ZnCl}_{2}$ activated carbon produced from coconut shell, and by Oliveira [12] in studies with zeolites. In these works, the maximum sulphate loadings observed were $55.6 \mathrm{mg} \mathrm{g}^{-1}, 4.9 \mathrm{mg} \mathrm{g}^{-1}$ and $53.8 \mathrm{mg} \mathrm{g}^{-1}$, respectively.

As predicted by constant $b$ in the Langmuir model, the van't Hoff equation (Eq. (8)) [27] confirmed that sulphate sorption by Amberlyst A21 is an exothermic process $\left(\Delta H=-25.06 \mathrm{~kJ} \mathrm{~mol}^{-1}\right)$ related to a decrease in entropy $\left(\Delta S=-0.042 \mathrm{~kJ} \mathrm{~mol}^{-1} \mathrm{~K}^{-1}\right)$ of the system (Fig. 4, Table 3). A study of sulphate sorption on activated carbon revealed it to be an endothermic process

Table 3

Changes of enthalpy, $\Delta H$, Gibbs free energy, $\Delta G$ and entropy, $\Delta S$, related to sulphate adsorption process by Amberlyst A21 resin, at $\mathrm{pH} 4$ and stirring rate of $180 \mathrm{~min}^{-1}$.

\begin{tabular}{llll}
\hline Temperatura $\left({ }^{\circ} \mathrm{C}\right)$ & $\Delta H\left(\mathrm{~kJ} \mathrm{~mol}^{-1}\right)$ & $\Delta S\left(\mathrm{~kJ} \mathrm{~mol}^{-1} \mathrm{~K}^{-1}\right)$ & $\Delta G\left(\mathrm{~kJ} \mathrm{~mol}^{-1}\right)$ \\
\hline 34 & & & -12.21 \\
50 & -25.06 & -0.042 & -10.25 \\
70 & & & -10.74 \\
\hline
\end{tabular}


(a)

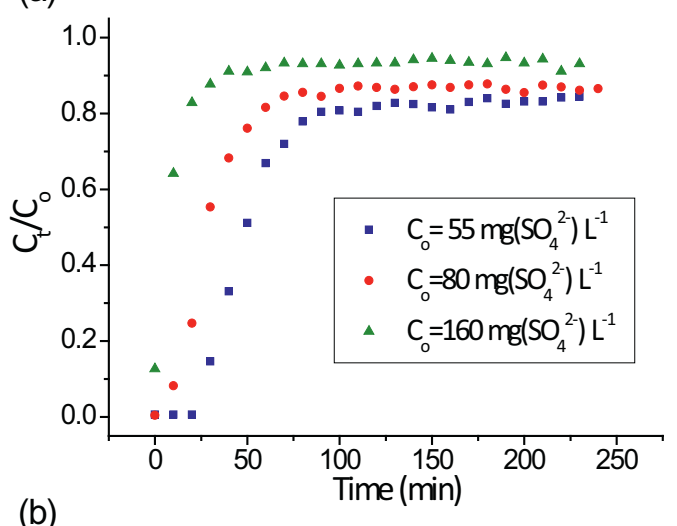

(b)

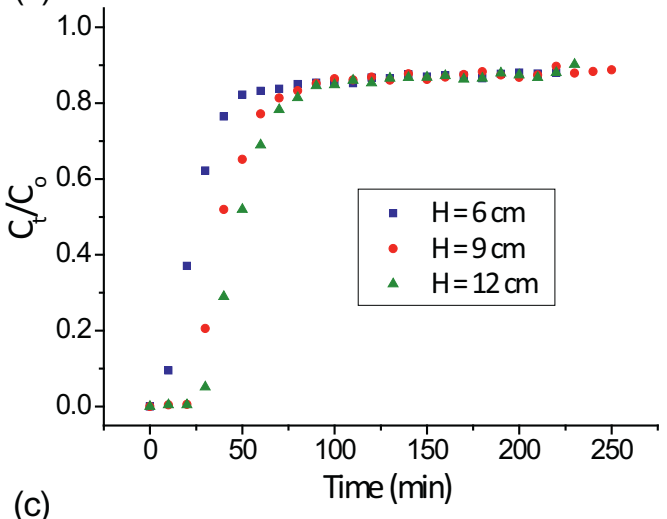

(c)

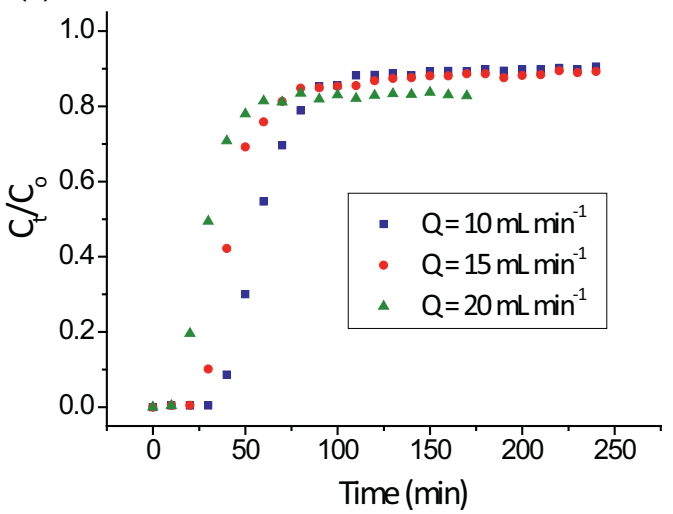

Table 4

Sulphate elution of Amberlyst A21 resin, at $30^{\circ} \mathrm{C}$ and stirring rate of $180 \mathrm{~min}^{-1}$

\begin{tabular}{lll}
\hline $\begin{array}{l}\text { Initial sulphate loading } \\
\left(\mathrm{mg}\left(\mathrm{SO}_{4}^{2-}\right) \mathrm{mL}(\text { resin })^{-1}\right)\end{array}$ & $\begin{array}{l}\text { Dessorption } \\
\text { efficiency }(\%)\end{array}$ & Eluant \\
\hline 10.4 & $\sim 100$ & $\begin{array}{l}\text { Solution of } \mathrm{NaOH} \\
(\mathrm{pH} \mathrm{10)})\end{array}$ \\
& $\sim 100$ & $\begin{array}{l}\text { Solution of } \mathrm{NaOH} \\
(\mathrm{pH} \mathrm{12})\end{array}$ \\
\end{tabular}

alkaline conditions, resulting in low sulphate loadings. Therefore, elution was carried out by setting the $\mathrm{pH}$ of the eluent solution to 10 and 12, which gave yields approaching 100\% (Table 4). Similar to the current study, Feng et al. [13] observed elution yields for the ion exchange resins Duolite A161, Duolite A375 and Amberlite IRA67 between $90 \%$ and $95 \%$ when applying $\mathrm{Ca}(\mathrm{OH})_{2}$ solutions containing $2 \% \mathrm{NaOH}$. Moreover, Moret and Rubio [7] observed nearly $96 \%$ sulphate elution from shrimp peelings functionalized with tertiary amine groups after increasing the $\mathrm{pH}$ to 12 . Efficient sulphate desorption from carbon produced from coconut shell and activated with $\mathrm{ZnCl}_{2}$ was also promoted in an alkaline medium ( $\mathrm{pH} 11$ ) with $90 \%$ efficiency [10].

\subsection{Fixed-bed experiments}

Fig. 5(a) and (b) presents the breakthrough curves produced from solutions containing different sulphate concentrations and bed depths, respectively, at a flow rate of $15 \mathrm{~mL} \mathrm{~min}^{-1}$. Table 5 depicts the measured sorption parameters. The curves demonstrate that either increasing the solution concentration or decreasing the bed depth resulted in reaching breakthrough and saturation points more rapidly; thus, a smaller volume of solution is treated at breakthrough. These outcomes were a result of the fact that the adsorption capacity is finite and was reached more rapidly at larger inlet concentrations or lower bed heights. Irrespective of the parameter investigated, the same capacities of approximately $10 \mathrm{mg}\left(\mathrm{SO}_{4}{ }^{2-}\right) \mathrm{mL}(\text { resin })^{-1}$ were determined. Fig. 5(c) and Table 5 demonstrate that increasing the flow rate reduced the time needed to reach the breakthrough and saturation points. Because increased flow rates imply less contact time between the resin and the solution, there was a slight reduction in sorption capacity to a value around $8 \mathrm{mg} \mathrm{mL}(\text { resin })^{-1}$, which is consistent with the study by Haghsheno et al. [21] on the resin Lewait K6362.

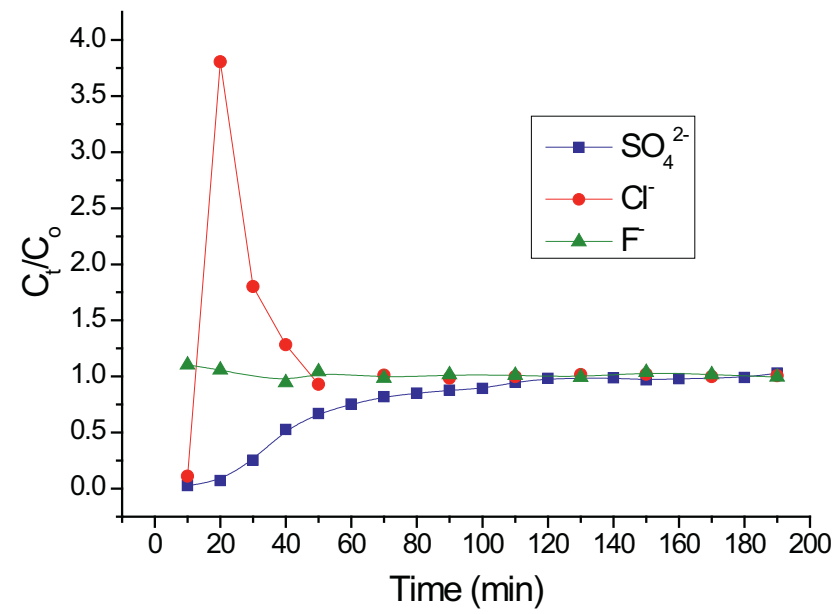

Fig. 6. Breakthrough curves for the adsorption of the major anions present in the metallurgical industry effluent treated in a fixed-bed of Amberlyst A21. Experimental conditions: $\mathrm{pH} 3.2,25 \pm 1^{\circ} \mathrm{C}$, bed height of $9 \mathrm{~cm}, 0.35$ bed porosity and flow rate of $10 \mathrm{~mL} \mathrm{~min}^{-1}$. 
Table 5

Experimental data obtained with fixed bed experiments carried out at $28 \pm 1{ }^{\circ} \mathrm{C}$, pH 4 , porosity of 0.35 , varying the sulphate inlet concentration, bed height and flow rate.

\begin{tabular}{|c|c|c|c|c|c|c|}
\hline $\begin{array}{l}\text { Varied } \\
\text { experimental } \\
\text { condition }\end{array}$ & $\begin{array}{l}\text { Breakthrough } \\
\text { volume (mL) }\end{array}$ & $\begin{array}{l}\text { Breakthrough } \\
\text { time (min) }\end{array}$ & $\begin{array}{l}\text { Saturation } \\
\text { volume }(\mathrm{mL})\end{array}$ & $\begin{array}{l}\text { Saturation time } \\
\text { (min) }\end{array}$ & $\begin{array}{l}\text { Bed capacity of } \\
\text { adsorption } \\
\left(\mathrm{mg}\left(\mathrm{SO}_{4}^{2-}\right)\right)\end{array}$ & $\begin{array}{l}\text { Maximum loading of resin } \\
\left(q_{\max }\right) \\
\left(\mathrm{mg}\left(\mathrm{SO}_{4}{ }^{2-}\right) \mathrm{mL}(\text { resin })^{-1}\right)\end{array}$ \\
\hline \multicolumn{7}{|c|}{$\begin{array}{l}\text { Sulphate inlet concentration } \\
\left(\mathrm{mg}\left(\mathrm{SO}_{4}{ }^{2-}\right) \mathrm{L}^{-1}\right)\end{array}$} \\
\hline 55 & 600 & 40 & 1500 & 100 & 93.8 & 8.52 \\
\hline 80 & 450 & 30 & 1200 & 80 & 105.7 & 9.61 \\
\hline 160 & 150 & 10 & 750 & 50 & 126.7 & 11.5 \\
\hline \multicolumn{7}{|l|}{$\begin{array}{l}\text { Bed height } \\
(\mathrm{cm})\end{array}$} \\
\hline 6 & 150 & 10 & 1200 & 80 & 101.6 & 12.7 \\
\hline 9 & 300 & 20 & 1350 & 90 & 111.6 & 10.1 \\
\hline 12 & 450 & 30 & 1650 & 110 & 138.7 & 9.6 \\
\hline \multicolumn{7}{|l|}{$\begin{array}{l}\text { Flow rate } \\
\left(\mathrm{mL} \mathrm{min}^{-1}\right)\end{array}$} \\
\hline 10 & 400 & 40 & 1100 & 110 & 88.5 & 8.1 \\
\hline 15 & 450 & 30 & 1200 & 80 & 95.6 & 8.7 \\
\hline 20 & 400 & 20 & 1200 & 60 & 96.8 & 8.8 \\
\hline
\end{tabular}

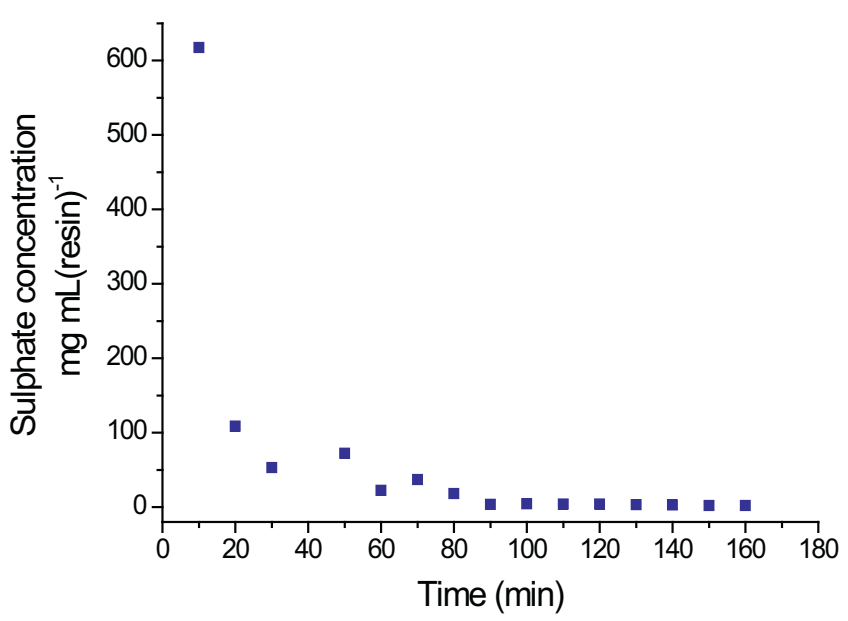

Fig. 7. Desorption curve of the bed loaded by the metallurgical effluent by using of sodium hydroxide ( $\mathrm{pH} 12$ ). Experimental conditions: $25 \pm 1{ }^{\circ} \mathrm{C}$, bed height of $9 \mathrm{~cm}$, 0.35 bed porosity and flow rate of $10 \mathrm{~mL} \mathrm{~min}^{-1}$.

Fig. 6 shows the breakthrough curve obtained in the experiments performed with an industrial effluent (Table 1). At low resin loadings, there were free tertiary amine functional groups and thus both chloride and sulphate ions were adsorbed. As these groups were occupied, a competition between chloride and sulphate was then observed. Because sulphate has a higher affinity for the resin, chloride overshooting was observed during the loading as indicated by $C_{t} / C_{o}$ ratios larger than 1 , for chloride. Therefore, no chloride loading on the resin was observed at the end of the experiment. That was confirmed by the desorption experiments whose results are presented in Fig. 7 and revealed no chloride in the eluate, i.e. only sulphate anions were detected. Furthermore, the industrial effluent also contained fluoride ions but the latter was not adsorbed at any moment.

Approximately $150 \mathrm{~min}$ were necessary to saturate the resin whose maximum loading was $14.27 \mathrm{mg}\left(\mathrm{SO}_{4}{ }^{2-}\right) \mathrm{mL}(\text { resin })^{-1}$ whereas approximately $80 \mathrm{~min}$ were required during elution. Resin loading in the experiment with the industrial effluent was higher than those obtained in batch tests (carried out at $\mathrm{pH} 4$ ). It is likely that the higher loading observed in the experiment with a real effluent is due to the $\mathrm{pH}$ of the effluent which was 3.2. According to Fig. 1, the lower the $\mathrm{pH}$, the higher the loading capacity of the resin due to its functional groups protonation (Eqs. (1) and (2)).

\section{Conclusions}

The present study showed the application of the ion exchange resin Amberlyst A21 in sulphate sorption for the first time. By a comprehensive investigation of different parameters related to its sulphate sorption performance, it was possible to conclude that the process has positive features that make it a good candidate for use in sulphate removal applications. In acidic conditions, the process is fast $\left(k=1.67 \times 10^{-4} \mathrm{~s}^{-1}\right)$, exothermic $\left(\Delta H=-25.06 \mathrm{~kJ} \mathrm{~mol}^{-1}\right)$ and can be carried out in both batch and fixed-bed columns with no difference in the maximum adsorption capacity $\left(11.6 \mathrm{mg}\left(\mathrm{SO}_{4}{ }^{2-}\right) \mathrm{mL}(\text { resin })^{-1}\right)$. Although this adsorption capacity is low compared to strong base resins, $100 \%$ resin elution is easily accomplished by increasing the $\mathrm{pH}$ to 10 and 12 with sodium hydroxide solutions. The experiments with an industrial effluent indicated that fluoride ions do not interfere on the sulphate loading. Conversely, although chloride was also loaded, it was later desorbed as the bed became saturated with sulphate, which had a higher affinity for the resin.

\section{Acknowledgements}

Financial support from the funding agencies FINEP, FAPEMIG, CNPq, CAPES and Vale is gratefully appreciated.

\section{References}

[1] INAP, Treatment of sulphate in mine effluentes, in: International Network for Acid Prevention, 2003, p. 129.

[2] WHO, in: Guidelines for Drinking-Water Quality, Genebra, 2008, p. 668.

[3] R.J. Bowell, Sulphate and salt minerals: the problem of treating mine waste, in: Mine Environmental Mangazine, 2000, pp. 11-13.

[4] A. Akcil, S. Koldas, Acid Mine Drainage (AMD): causes, treatment and case studies, J. Cleaner Prod. 14 (2006) 1139-1145. 
[5] USEPA, in: Sulfate in Drinking Water, U.S. Environmental Protection Agency, Washington, DC, 1999.

[6] T.D. Reynolds, P. Richards, Unit Operations and Processes in Environmental Engineering, 2nd ed., PWS Publishing Company, Boston, 1995.

[7] A. Moret, J. Rubio, Sulphate and molybdate ions uptake by chitin-based shrimp shells, Miner. Eng. 16 (2003) 715-722.

[8] D.R. Mulinari, M.L.C.P. da Silva, Adsorption of sulphate ions by modification of sugarcane bagasse cellulose, Carbohydr. Polym. 74 (2008) 617-620.

[9] W. Cao, Z. Dang, X.-Q. Zhou, X.-Y. Yi, P.-X. Wu, N.-W. Zhu, G.-N. Lu, Removal of sulphate from aqueous solution using modified rice straw: preparation, characterization and adsorption performance, Carbohydr. Polym. 85 (2011) 571-577.

[10] C. Namasivayam, D. Sangeetha, Application of coconut coir pith for the removal of sulfate and other anions from water, Desalination 219 (2008) 1-13.

[11] A.M. Silva, R.M.F. Lima, V.A. Leão, Mine water treatment with limestone for sulfate removal, J. Hazard. Mater. 221-222 (2012) 45-55.

[12] C.R. Oliveira, Adsorção - remoção de sulfato e isopropilxantato em zeólita natural funcionalizada, MSc, Universidade Federal do Rio Grande do Sul, Porto Alegre, 2006, 107 pp.

[13] D. Feng, C. Aldrich, H. Tan, Treatment of acid mine water by use of heavy metal precipitation and ion exchange, Miner. Eng. 13 (2000) 623-642.

[14] D. Guimarães, Tratamento de Efluentes Ricos em Sulfato por Adsorção em Resina de Troca-Iônica, Master Thesis, Universidade Federal de Ouro Preto, Ouro Preto, MG, Brasil, 2010, 170 pp.

[15] H. Qiu, L. Lv, B.C. Pan, Q.J. Zhang, W.M. Zhang, Q.X. Zhang, Critical review in adsorption kinetic models, J. Zhejiang Univ. Sci. A 10 (2009) 716-724.
[18] Y.S. Ho, G. McKay, Pseudo-second order model for sorption processes, Process Biochem. 34 (1999) 451-465.

[19] J. Weber, J.C. Morris, Kinetics of adsorption on carbon solution, J. Sanit. Eng. 89 (1963) 31-59.

[20] M. Chabani, A. Amrane, A. Bensmaili, Kinetic modelling of the adsorption of nitrates by ion exchange resin, Chem. Eng. J. 125 (2006) 111-117.

[21] R. Haghsheno, A. Mohebbi, H. Hashemipour, A. Sarrafi, Study of kinetic and fixed bed operation of removal of sulfate anions from an industrial wastewater by an anion exchange resin, J. Hazard. Mater. 116 (2009) 961-966.

[24] S.S. Tahir, N. Rauf, Thermodynamic studies of Ni(II) adsorption onto bentonite from aqueous solution, J. Chem. Thermodyn. 35 (2003) 2003-2009.

[25] H. Zheng, L. Han, H. Ma, Y. Zheng, H. Zhang, D. Liu, S. Liang, Adsorption characteristics of ammonium ion by zeolite 13X. J. Hazard. Mater. 158 (2008) 577-584.

[26] B. Kemer, D. Ozdes, A. Gundogdu, V.N. Bulut, C. Duran, M. Soylak, Removal of fluoride ions from aqueous solution by waste mud, J. Hazard. Mater. 168 (2009) 888-894.

[27] E.L. Schineider, Adsorção de compostos fenólicos sobre carvão ativado, 93 pp. Universidade Estadual do Oeste do Paraná, Toledo, 2008.

[28] G. Bayramoglu, B. Altintas, M.Y. Arica, Adsorption kinetics and thermodynamic parameters of cationic dyes from aqueous solutions by using a new strong cation-exchange resin, Chem. Eng. J. 152 (2009) 339-346.

[29] D.O. Cooney, Adsorption Design for Wastewater Treatment, Lewis Publishers, Boca Raton, 1999. 